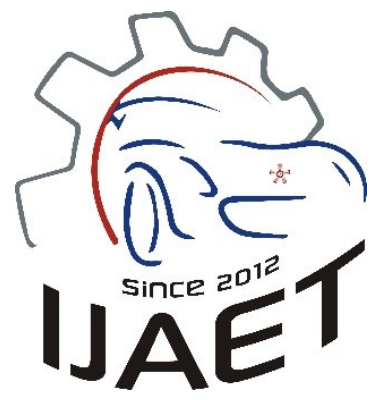

e-ISSN: 2146 - 9067

International Journal of Automotive

Engineering and Technologies

journal homepage: http://ijaet.academicpaper.org

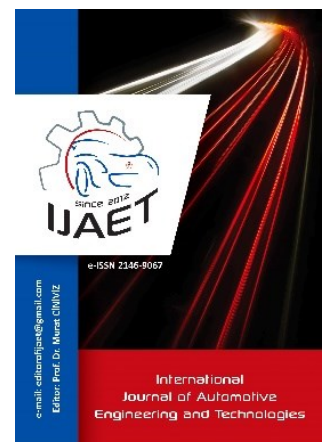

Original Research Article

\title{
Flame radius effects on a sequential ignition engine characteristics
}

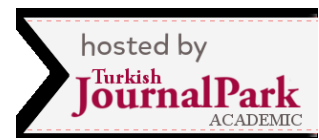

\author{
Ahmet Alper Yontar ${ }^{*}$, Yahya Doğu ${ }^{2}$ \\ ${ }^{1}$ Mersin University, Tarsus Faculty of Technology, Department of Automotive Engineering, Mersin, Turkey \\ ${ }^{2}$ Kırıkkale University, Faculty of Engineering, Department of Mechanical Engineering, Kırıkkale, Turkey
}

\begin{abstract}
ARTICLE INFO
* Corresponding author

ahmetyontar@mersin.edu.tr

Received: June 21, 2017

Accepted: March 12, 2018

Published by Editorial Board Members of IJAET

(C) This article is distributed by Turk Journal Park System under the CC 4.0 terms and conditions.
\end{abstract}

\begin{abstract}
The effects of the flame radius and flame propagation have been investigated for a sequential ignition engine with numerically. A single cylinder of the sequential ignition engine was modeled in STAR-CD/es-ice software for the gasoline usage taking into account all components related to the combustion chamber. The effect of flame on engine characteristics is the function of flame radius and flame thickness. In the numerical analysis, compression ratio is 10.8:1, airfuel ratio is 1.2, ignition advance at $30-25 \mathrm{CAD}$, engine speed is $3000 \mathrm{rpm}$ and the flame thickness is $0.0001 \mathrm{~m}$ were kept constant. The analysis, k- $\varepsilon$ RNG turbulence model, Angel Berger wall interaction and G-equation combustion model were used and optimum flame radius value was determined. Three different analysis were carried out to determine the effect of the flame radius and the flame radius was changed to $0.0005 \mathrm{~m}, 0.0010 \mathrm{~m}$ and $0.0020 \mathrm{~m}$, respectively. As a result of the study, images of flame formation and propagation were obtained for the time period up to the top dead center at the time of sequential ignition. The effects of flame radius on $\mathrm{CO}_{2}$ formation and $\mathrm{NO}_{x}$ formation were evaluated. The network area was obtained from the highest engine power and pressure-volume graph when the flame radius was $0.0010 \mathrm{~m}$ for the specified operating conditions.
\end{abstract}

Keywords: Flame Radius, Combustion Modelling, Flame Propagation, Engine Characteristics, $\mathrm{CO}_{2}, \mathrm{NO}_{\mathrm{x}}$

\section{Introduction}

The effects of technological advances are also seen in the automotive world. R\&D investments are being made in the automotive sector on vehicle engines, vehicle structure, vehicle control systems and powertrain. The $\mathrm{R} \& \mathrm{D}$, focuses on engine characteristics and continues with increasing momentum every day. Experimental research on internal combustion engines, one of the most important research areas of the automotive field, requires high costs and time-consuming. The importance of numerical modeling studies (1-D, 3-D, etc.) for internal combustion engine is increasing day by day and numerical modeling studies save time and reduce costs. All operating conditions of the engine are examined in detail by experimental and numerical analysis methods and optimum working parameters are tried to be determined and controlled.

Engine modeling studies are carried out through 1-D modeling and 3-D modeling methods. In this context, many software is used 
such as STAR-CD/es-ice, AVL-Fire, GT-Power and Ricardo-Wave etc. Through the studies carried out in the numerical modeling software, many results can be obtained about the actual engine behavior. The effect of many parameters on engine characteristics can be examined ultimately with the numerical modeling software. Examples of these parameters: loading conditions, flame propagation techniques, compression ratio, combustion mechanisms, alternative fuel additives, alternative fuel usage, combustion chamber geometry, etc.

As can be seen in the literature, it was conducted several studies on the engine modelling and flame propagation by this time. Chen et al. [1], investigated to spherical flame structure using with asymptotic analysis and numerical simulations. They determined to the critical flame radius is larger than the flame thickness and the minimum ignition energy is a function of the critical flame radius. Malaguti and Fontanesi [2], investigated the formation of liquid film and the development of spraying in a commercial-engineered combustion chamber with spark ignition by means of computational fluid dynamics at low temperature operating conditions with STAR-CD/es-ice software. Yontar et al. [3] demonstrated the effects of ignition advance on flame propagation, engine performance and exhaust emissions in sparkignition engines in their work. They performed numerical analysis by modeling the single cylinder of the four-cylinder engine with spark plug ignition via the STAR-CD/es-ice software and analyzes for each advance value in the range of 10-70 CAD from the top dead center. They determined that the optimum ignition advance was 50 CAD from the top dead center in terms of engine performance and exhaust emissions. Kelley and Law [4], examined to various factors effecting the determination of laminar flames speeds. They suggested that the laminar flame speed from expanding spherical flames can be facilitated by using small ignition energy and a large combustion chamber. Huang et al. [5] investigated to laminar flame characteristics and effects of flame radius. They determined to the flame radius increases with time but the increasing rate decreases with flame expansion for lean mixture combustion. Dowdy et al. [6] used a new technique for determining burning velocities via flame radius. A phenomenological model has been developed to obtain the 1-D flame speed by extrapolation to infinite radius. Kelly et al. [7] investigated to critical radius for sustained propagation of spark-ignited flames. They determined to sustained propagation depends on whether the initially ignited flame can attain a minimum radius according to Lewis number. Hepkaya et al. [8], used Coherent Flame Model for visualize fluid flow and combustion characteristics of a single cylinder spark ignition engine via Star-CD/es-ice software. They observed that CFM predicts faster flame propagation and reaches higher temperature and pressure compared to experimental data. Deshaies and Joulin [9], used asymptotic expansions for the initiation of a spherical flame Kernel in their works. They focused on two means to modify, or even suppress, such a critical flame size. As a result, they developed a correlation with the development of Kernel flame. Pischinger and Heywood [10], investigated about the Kernel flame propagation model for a spark-ignition engine. The purpose of their study was to show how the physics equations relevant to flame growth. They determined to the Kernel grows more slowly with higher heat losses about up to $1.5 \mathrm{~mm}$ Kernel flame radius.

In this study, an intelligent dual-sequential engine was 3-D numerically modelled via STAR-CD/es-ice and the flame propagation and engine characteristics were analyzed.

\section{CFD Modelling}

This work focuses on determined optimum flame radius via numerical simulation of flame propagation in a cylinder with STAR-CD/es-ice software. In the 3-D cylinder model was built including the entire cylinder from the beginning of the intake port to the end of the exhaust port. Technical specifications of the modelled sequential spark ignition engine are given in Table 1.

A solid model of all geometric details surrounding the cylinder combustion volume is required for 3-D combustion modelling. Modeled Honda L13A4 i-DSI (Intelligent Dual Sequential Ignition) commercial engine has a very different and non-standard in-cylinder combustion geometry. This engine's intake port is designed for high swirl ratio (1.10-1.36) and tumble ratio (1.30-1.58) for strengthens 
turbulent motion at the compression and raise the flame propagation speed. Fuel is injected into the intake port behind the intake valve thus fuel-air mixture is fed into the cylinders. There are two spark plugs located in different zones in the cylinder. The spark plugs are positioned closer to the intake and the exhaust valve sides. The sequential ignition system ignites at the same speed in the idle state and above $4000 \mathrm{rpm}$. The piston combustion chamber of the engine is completely asymmetrical. The cylinder head structure is a pent-roof head [11-12]. The cylinder modelling phase, dimensions of related engine parts are measured with a CMM device. Then, each cylinder parts (piston, cylinder, ports, valves and spark plugs) are separately formed in CAD software (Figure 1). The parts are then assembled and the enclosed volume created. Figure 2 also shows images of the parts forming the combustion chamber.

Table 1. Specifications of the engine

\begin{tabular}{ll}
\hline Engine model & $\begin{array}{l}\text { Honda L13A4 i- } \\
\text { DSI }\end{array}$ \\
\hline Displacement, cc & 1339 \\
Bore, $\mathrm{m}$ & 0.073 \\
Stroke, $\mathrm{m}$ & 0.080 \\
Compression ratio & $10.8: 1$ \\
Number of cylinders & 4 \\
Max. torque, Nm/rpm & $119 / 2800$ \\
Max. power, $\mathrm{kW} / \mathrm{rpm}$ & $63 / 5700$ \\
\hline
\end{tabular}

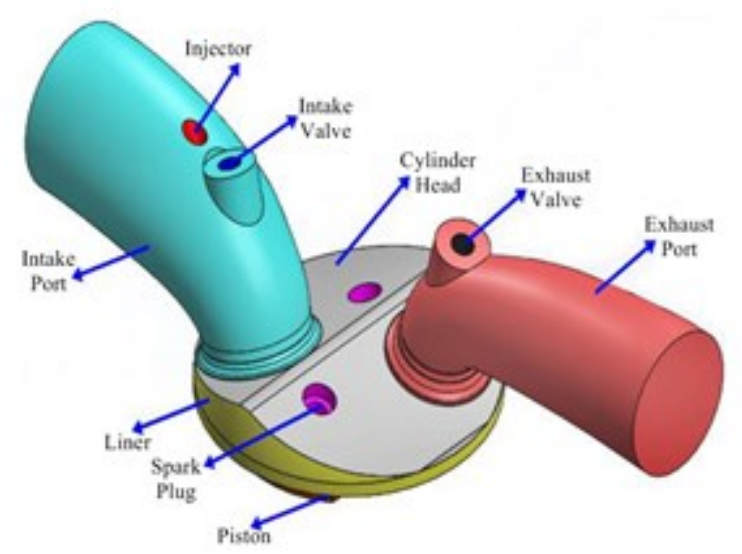

Figure 1. Parts of cylinder components

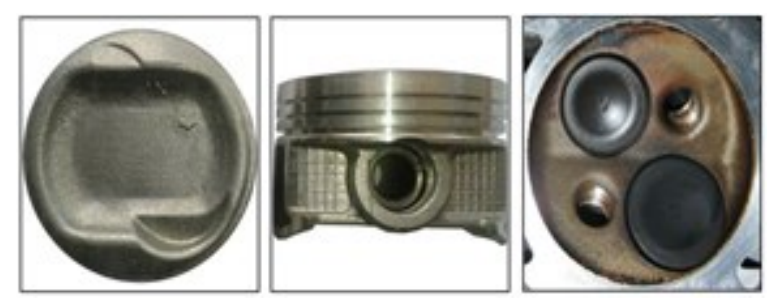

Figure 2. Parts of combustion chamber
The creation of the 3-D combustion model requires knowledge and experience on both the theoretical and the capabilities of the modeling programs as well as the great effort and time involved, especially moving parts such as pistons, valves and transient behaviors. The 3-D in-cylinder combustion model contains many complex physics.

Trimming method was used in the study. Trimming consists of the following steps, respectively: modify geometry cell sets, create splines, create $2 \mathrm{D}$ base template, create $3 \mathrm{D}$ template, trim the template, add extrusion cells to port faces, assemble the template, STAR setup, create results and STAR controls [13]. The mesh process, definition of fixed and moving regions in the cylinder combustion geometry was made. The 2-D mesh templates were created to make 3-D dynamic mesh structures. These 2-D mesh templates are then converted to 3-D mesh templates. Approximately 1200000 mesh elements are used in the model. The mesh structure is shown in Figure 3.

The analysis, k- $\varepsilon$ RNG turbulence model, Angelberger wall interaction and G-equation combustion model were used as detailed combustion definitions. G-equation combustion model [13]; A scalar called burnt and unburned region $\mathrm{G}$ is separated by an equivalent surface (iso-surface: $G$ and $G^{\prime}$ ). It is a model used to describe the flame propagation, the turbulence interaction and the chemical structure of the mixture.

The transport equations for the variance $\mathrm{G}^{\prime}$ of $\mathrm{G}$ and $\mathrm{G}, \mathrm{c}_{\mathrm{s}}=2$ and $\mathrm{S}_{\mathrm{T}}$ are the calculated turbulent flame velocities.

$$
\begin{aligned}
& \frac{\partial}{\partial \mathrm{t}} \rho G+\frac{\partial}{\partial \mathrm{x}_{\mathrm{i}}} \rho \mathrm{u}_{\mathrm{i}} G=\rho \mathrm{S}_{\mathrm{T}}|\nabla G| \\
& \frac{\partial}{\partial \mathrm{t}} \rho \mathrm{G}^{\prime}+\frac{\partial}{\partial \mathrm{x}_{\mathrm{i}}} \rho \mathrm{u}_{\mathrm{i}} \mathrm{G}^{\prime}-\rho \mathrm{S}_{\mathrm{T}} \frac{\nabla \mathrm{G}^{\prime} . \nabla \mathrm{G}}{|\nabla \mathrm{G}|}= \\
& 2 \frac{\mu_{\mathrm{t}}}{\sigma_{\mathrm{t}}}\left[\frac{\partial \mathrm{G}^{\prime}}{\partial \mathrm{x}_{\mathrm{i}}} \frac{\partial \mathrm{G}}{\partial \mathrm{x}_{\mathrm{i}}}\right]-\mathrm{c}_{\mathrm{s}} \rho \frac{\varepsilon}{\mathrm{k}} \mathrm{G}^{\prime}
\end{aligned}
$$

$|\nabla G|=1$, must be provided in order to provide the determination $\mathrm{G}$ of the conditional distance function. Under normal conditions, the $G$ transport equation cannot provide this condition. Thus, a re-initialization process is required to ensure that $G$ outside the $G=0$ equivalent 
surface is a specified distance function. This is an acknowledgment for the definition of a discrete flame front. First, the points where the $\mathrm{G}$ function crosses its own zero are formed by linear interpolation. Subsequently, the minimum distance $\mathrm{d}$ and $\mathrm{G}$ function calculated from the center of each cell of the discrete flame front is aligned with the distance [13].

The temperature of burned gas and the turbulent flame velocity are expressed as:

$$
\begin{aligned}
& \mathrm{T}_{\mathrm{u}}=\mathrm{T}_{0}\left(\frac{\mathrm{P}}{\mathrm{P}_{0}}\right)^{\frac{\gamma-1}{\gamma}} \\
& \mathrm{S}_{\mathrm{T}}(\Phi)=\mathrm{S}_{1}^{0}(\Phi)\left[1+\mathrm{A}\left(\frac{\mathrm{u}^{\prime}}{\mathrm{S}_{1}^{0}(\Phi)}\right)^{5 / 6}\right] \\
& \mathrm{u}^{\prime}=\left(\frac{2}{3} \mathrm{k}\right)^{\frac{1}{2}}
\end{aligned}
$$

The turbulent flame velocity is then averaged over the mixture ratio:

$$
\mathrm{S}_{\mathrm{T}}=\int_{0}^{1} \mathrm{~S}_{\mathrm{T}}(\Phi) \mathrm{P}(Z) \mathrm{dZ}
$$

The ignition occurs at the instant $t=t_{\text {ig }}$ when the flame core is initiated in the spark plug location. After the initialization, the $G$ field is subjected to the reboot process. If only one point of ignition is present, the intensity of the turbulence rate is gradually increased during ignition:

$$
\begin{aligned}
& \mathrm{u}^{\prime}=\mathrm{u}_{0}^{\prime} \cdot \mathrm{f}(\mathrm{t})
\end{aligned}
$$

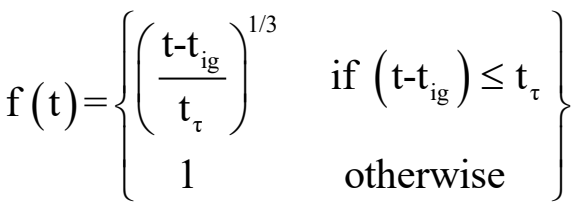

In the above expressions, $t_{i g}$ is the ignition start time and $t_{\tau}=\mathrm{k} / \varepsilon$ or the user defined turbulence time scale [13].

For the calculation of emissions; there are two alternative reaction mechanisms for $\mathrm{CO}$ and $\mathrm{CO}_{2}$ kinetics chemistry. The first consists of a simple reversible mechanism. Secondly, the oxidation mechanism of for steps is presented as an alternative to simple mechanism. Here, the fuel is first cracked into $\mathrm{C}_{2} \mathrm{H}_{4}$ and $\mathrm{CO}, \mathrm{H}_{2}$ are oxidized and transformed into $\mathrm{CO}_{2}$ and $\mathrm{H}_{2} \mathrm{O}$ [13].

$$
\begin{aligned}
& \mathrm{CO}+\mathrm{OH} \Leftrightarrow \mathrm{CO}_{2}+\mathrm{H} \\
& \mathrm{F}_{\mathrm{b}} \Leftrightarrow \mathrm{C}_{2} \mathrm{H}_{4}+\mathrm{H}_{2}
\end{aligned}
$$

$$
\begin{aligned}
& \mathrm{C}_{2} \mathrm{H}_{4}+\mathrm{O}_{2} \Leftrightarrow 2 \mathrm{CO}+2 \mathrm{H}_{2} \\
& \mathrm{CO}+(0.5) \mathrm{O}_{2} \Leftrightarrow \mathrm{CO}_{2} \\
& \mathrm{H}_{2}+(0.5) \mathrm{O}_{2} \Leftrightarrow \mathrm{O}_{2}+\mathrm{H}_{2} \mathrm{O}
\end{aligned}
$$

$\mathrm{NO}_{\mathrm{x}}$ chemistry, the classical extended 3-step Zel'dovich mechanism is solved. Related reactions are listed below [13].

$$
\begin{aligned}
& \mathrm{O}+\mathrm{N}_{2} \Leftrightarrow \mathrm{N}+\mathrm{NO} \\
& \mathrm{O}_{2}+\mathrm{N} \Leftrightarrow \mathrm{O}+\mathrm{NO} \\
& \mathrm{N}+\mathrm{OH} \Leftrightarrow \mathrm{H}+\mathrm{NO}
\end{aligned}
$$

Ignition advancement is used as 30-25 CAD. The ignition difference between the two spark plugs is determined by the electronic control unit (ECU) of the engine between 2-5 CAD depending on the engine speed [12]. The mixture to the in-cylinder is set to pre-mixed. As boundary conditions; cylinder head temperature, piston top zone temperature, cylinder wall temperature are defined in the software and the determination of these values has been benefited from the studies in the literature [14-15-16]. Ports and valve surfaces are adiabatically defined.

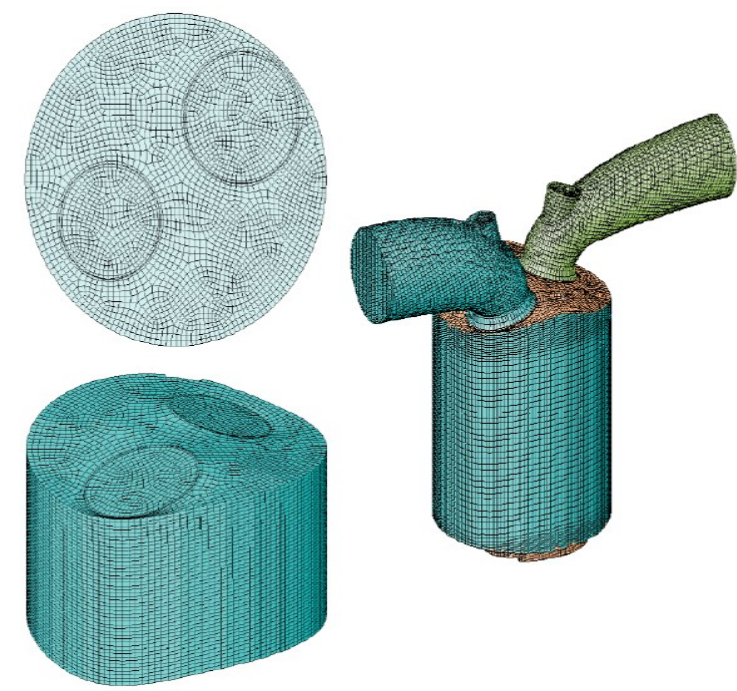

Figure 3. Mesh structure of cylinder

PISO (Pressure Implicit with Split Operator) algorithm implements a predictive-correction strategy. It temporarily separates the flow equations from each other and allows them to be solved in order. The algorithm was used to solve the equations. MARS (Monotone Advection and Reconstruction Scheme) method provides high sensitivity to network structure and network structure errors according to other discretization schemes. The MARS formulation is used for the resolution method in the 3-D analysis. 
Three different analysis were carried out to determine the effect of the flame radius and the flame radius was changed to $0.0005 \mathrm{~m}, 0.0010$ $\mathrm{m}$ and $0.0020 \mathrm{~m}$, respectively. The resolutions were performed for a range of 320 - $1080 \mathrm{CAD}$ for each 0.1 CAD take into account the valves opening / closing advances (Table 2).

Table 2. Times and solution intervals

\begin{tabular}{|c|c|c|}
\hline Intervals & $\begin{array}{c}\text { Starting } \\
\text { time } \\
(\mathrm{CAD})\end{array}$ & $\begin{array}{c}\text { Ending } \\
\text { time } \\
\text { (CAD) } \\
\end{array}$ \\
\hline Solution & 320 & 1080 \\
\hline Cycle & 360 & 1080 \\
\hline $\begin{array}{l}\text { Intake valve } \\
\text { opening period }\end{array}$ & 339 & 605 \\
\hline $\begin{array}{l}\text { Exhaust valve } \\
\text { opening period }\end{array}$ & 841 & 375 \\
\hline
\end{tabular}

\section{Results and Discussion}

Three different analysis have been carried out to determine the effect of optimum flame radius in modeling. At the moment of ignition, first the spark plug is close to the intake port and the Kernel flame is formed and when this flame tends to grow, the spark plug close to the exhaust port ignites, causing the flame to progress rapidly through the cylinder. At first, due to the ignition of the spark plug, the laminar flame occurs and suddenly it becomes turbulent. This flame core grows almost spherically until it reaches the combustion chamber walls due to the low average speed and turns into a turbulent flame. The turbulent flame progresses layer by layer.

When the mixture is ignited with a spark, the combustion wave at the beginning is like a premixed flame. However, the gas in front of the flame front is to be compressed and heated. If this condition is sufficient to initiate selfignition, a knock-on combustion occurs in the unburned fuel zone. Spark plug gap, spark plug voltage etc. factors affect the flame radius and ignition advance setting.

This flame reaches the cylinder wall at about 1.6 ms. There are 5 CAD times between two ignition moment in the number of revolutions. In this analysis, the flame radius was changed to $0.0005 \mathrm{~m}, 0.0010 \mathrm{~m}$ and $0.0020 \mathrm{~m}$. In addition, the flame thickness is kept constant at $0.0001 \mathrm{~m}$.
For all flame radii, the pressure increases with compression and increases rapidly from the moment of ignition and decreases after reaching the peak point. The effects of the flame radius on the pressure of in-cylinder take place in Figure 4. For the engine power to be obtained, it is not enough to consider only the in-cylinder pressure. For the evaluation of the network area obtained from the cylinder, it is necessary to take into account the indicator diagram which is the cylinder pressure-volume change.

When calculating network areas using pressurevolume change (indicator) graph in Figure 5, it is seen that the largest network area is at radius of $0.0010 \mathrm{~m}$. An important point for spark ignition engines is to determine the value of the flame radius for the case where the losses are reduced and the highest peak pressure is achieved for other cycles.

The effects of the flame radius on the cylinder temperature are given in Figure 6. For all flame radii, the temperature inside the cylinder which increases at the time of compression increases rapidly from the moment of ignition and gradually decreases with a gradual lower slope after reaching the peak point. At the flame radius of $0.0005 \mathrm{~m}$, when the flame reaches the top dead center, the flame is not fully developed and the temperature inside the cylinder drops due to the start of the expansion time. The flame radii of $0.0010 \mathrm{~m}$ and $0.0020 \mathrm{~m}$, penetrate all the points in the cylinder, and the thermal energy of the fuel becomes large and the temperatures rise. Figure 7 shows the flame radius effects on the engine main characteristics (power, torque, bsfc (brake specific fuel consumption)). Maximum engine power was obtained at a flame radius of $0.0010 \mathrm{~m}$. The lowest engine power value is observed at a radius of $0.0005 \mathrm{~m}$ and at 0.0020 $\mathrm{m}$ flame radius gives engine power close to this engine power. In order to obtain the highest performance values in internal combustion engines, it is desirable to reach the maximum incylinder pressure at the beginning of the expansion time. At this point, because of the higher net work area at $0.0010 \mathrm{~m}$ flame radius, the torque and power obtained is higher than other flame radii. The lowest specific fuel consumption is achieved at a radius of 0.0010 $\mathrm{m}$.

The effects of flame radius on $\mathrm{CO}_{2}$ formation are given in Figure 8. When the flame diameter 
is $0.0005 \mathrm{~m}$, the flame propagation is slow. For this reason, the flame cannot penetrate every point in the cylinder. Depending on this situation, incomplete combustion products are increased. As a result, $\mathrm{CO}_{2}$ that it is a completed combustion product is reduced. As can be seen from $\mathrm{CO}_{2}$ curves, $\mathrm{CO}_{2}$ formation is lower than other flame radii, at $0.0005 \mathrm{~m}$ flame radius. When the flame radius is $0.0020 \mathrm{~m}$, the flame progresses quickly in-cylinder. Therefore, all the mixture in the cylinder is exhausted. As a result, when the incomplete combustion products are reduced, $\mathrm{CO}_{2}$ that it is a completed combustion product is increased.

The flame radius effect on $\mathrm{NO}_{\mathrm{x}}$ formation are given in Figure 9. In whole heat engines, $\mathrm{NO}_{\mathrm{x}}$ is a function of temperature.

$\mathrm{NO}_{\mathrm{x}}$ is the result of $\mathrm{N}_{2}$ and $\mathrm{O}_{2}$ molecules entering air into the cylinder reacting with each other at high temperatures. The $\mathrm{N}_{2}$ molecules which undergo thermal decomposition with increasing temperature react with $\mathrm{O}_{2}$ to form $\mathrm{NO}_{\mathrm{x}}$ compounds such as $\mathrm{NO}, \mathrm{NO}_{2}, \mathrm{NO}_{3}$ etc. In this context, the software calculates the $\mathrm{NO}_{\mathrm{x}}$ formations using the Zel'dovich mechanisms [17]. When the $\mathrm{NO}_{\mathrm{x}}$ fraction graph is examined, it is observed that the $\mathrm{NO}_{\mathrm{x}}$ formation for the $0.0005 \mathrm{~m}$ flame radius is lower. This behavior is supported by the in-cylinder temperature graph (Figure 6). At a radius of $0.0005 \mathrm{~m}$, the flame propagates more slowly and moves closer to the Low Temperature Combustion [18] region as a general behavior. Therefore, the chemical reactions occur at lower temperatures than other flame radii.

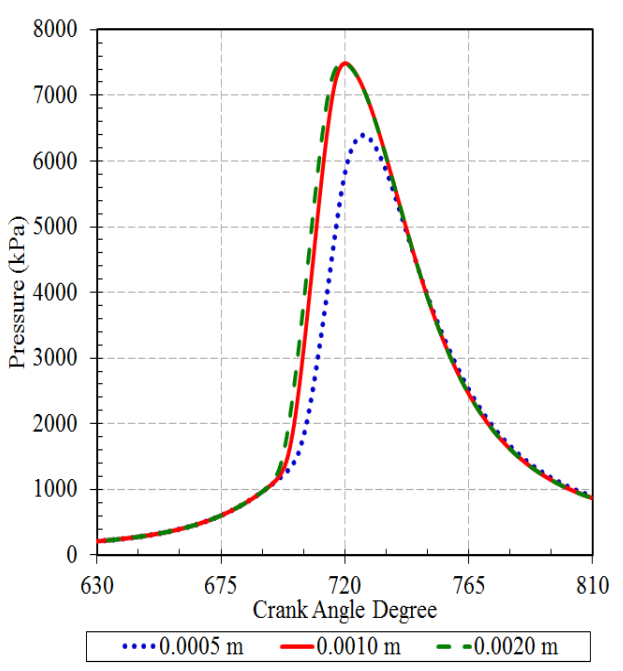

Figure 4. Pressure of in-cylinder.

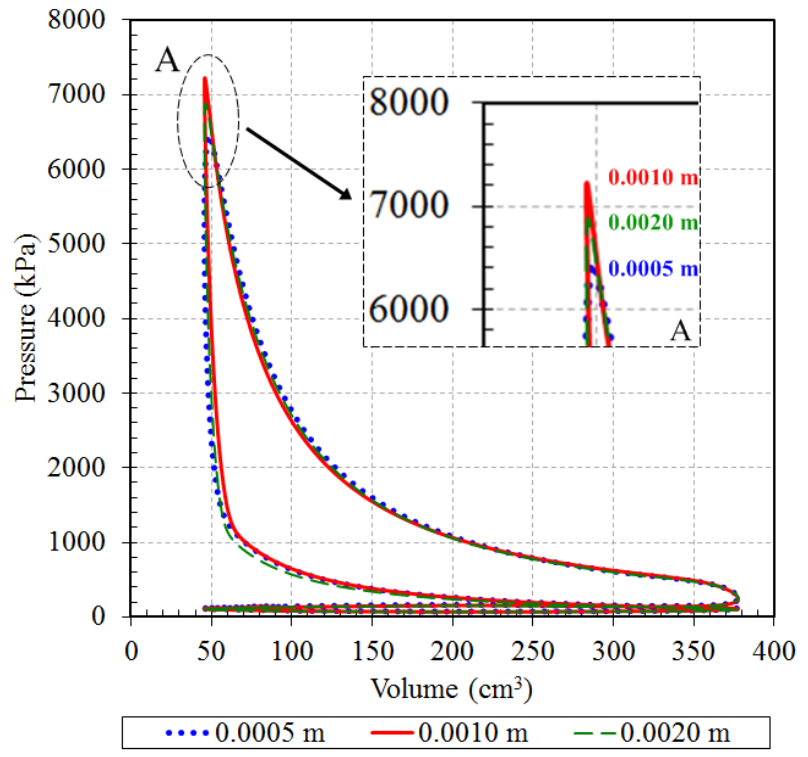

Figure 5. Indicator diagrams

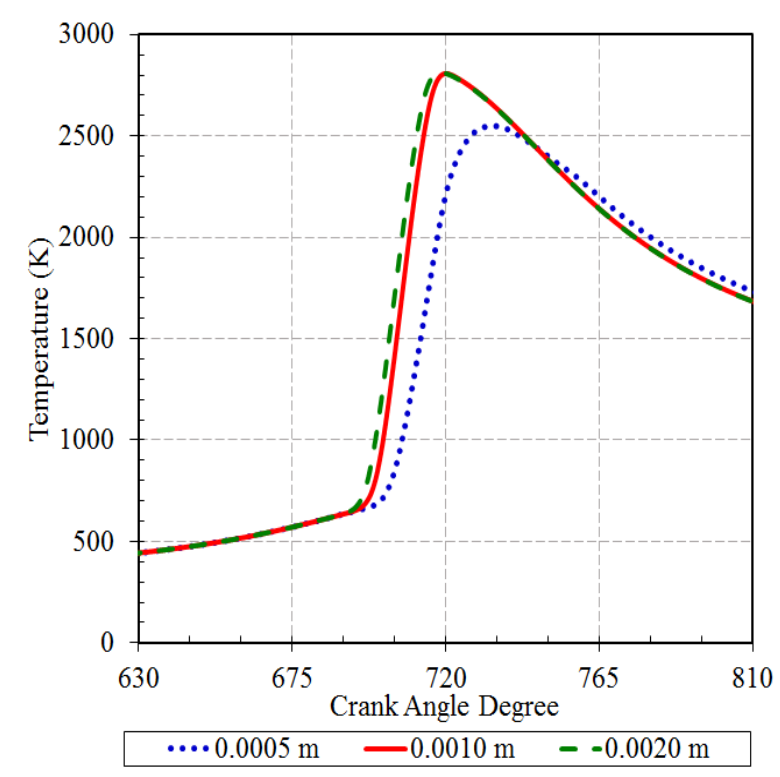

Figure 6. Temperature of in-cylinder

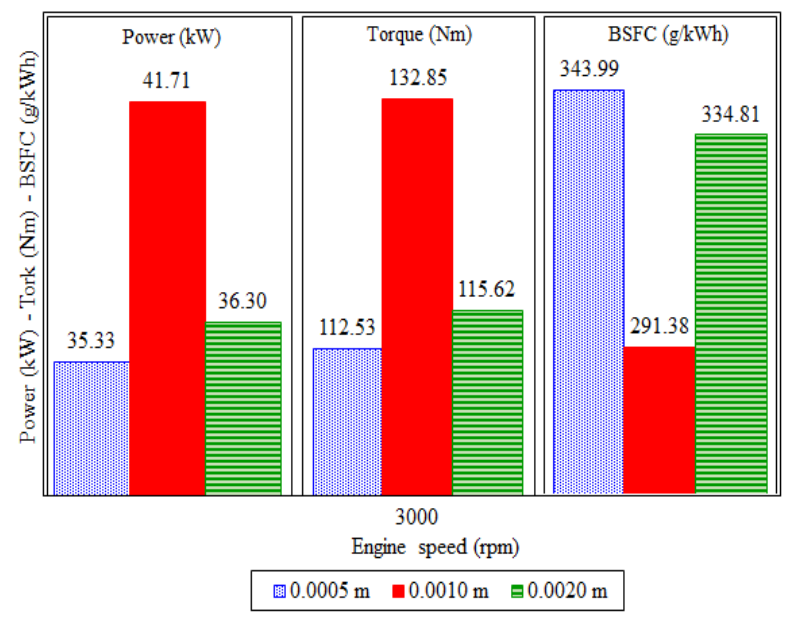

Figure 7. Flame radii vs. engine charact. 


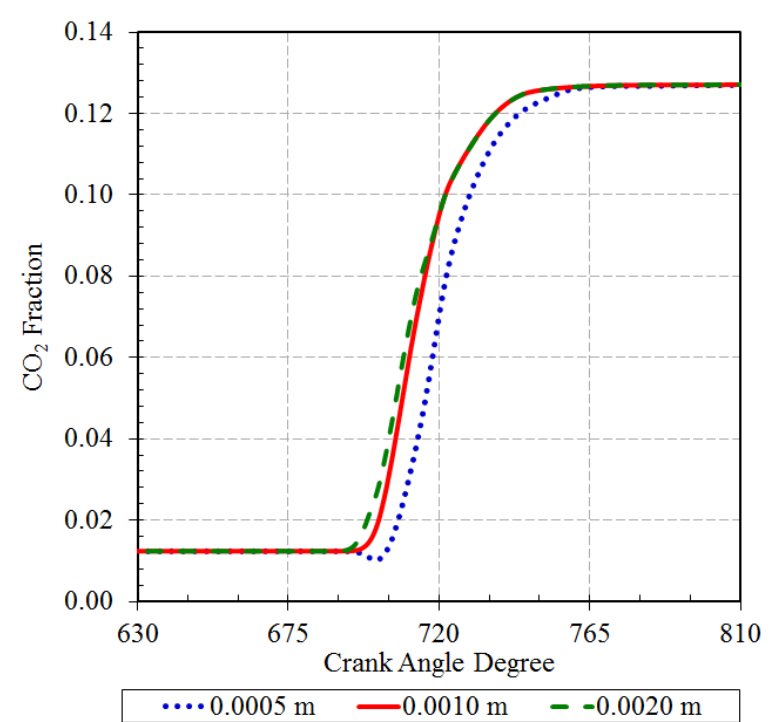

Figure 8. $\mathrm{CO}_{2}$ fractions

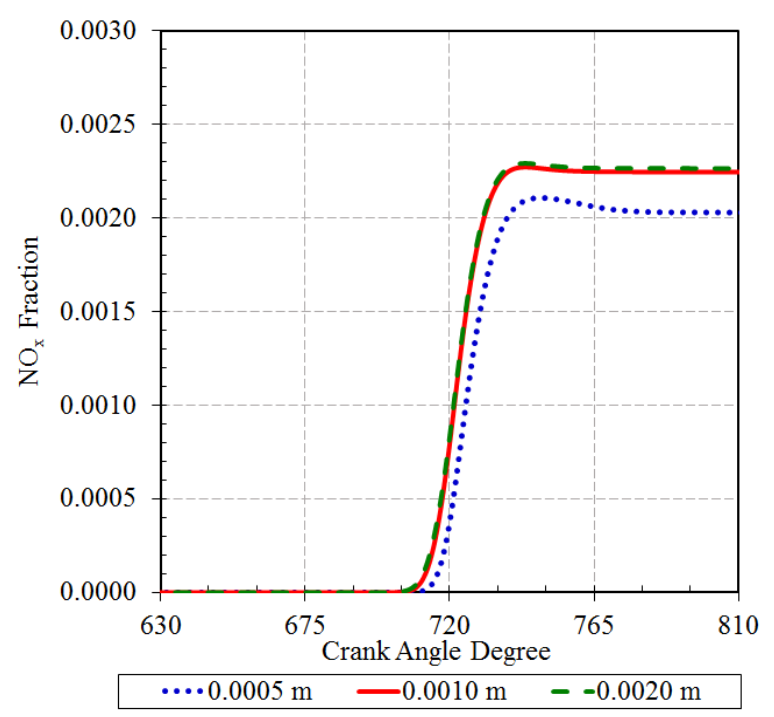

Figure 9. $\mathrm{NO}_{\mathrm{x}}$ fractions

The low temperature inside the cylinder reduces the possibility of thermal decomposition so that unstable molecules do not form. As a result, the amount of $\mathrm{NO}_{\mathrm{x}}$ formation remains at low levels. The amount of $\mathrm{NO}_{\mathrm{x}}$ is higher than $0.0005 \mathrm{~m}$ flame radius because of the temperatures are at high levels at $0.0020 \mathrm{~m}$ flame radius.

The effects of flame radius on flame formation and propagation are given in Figure 10 via temperature contours. When the flame radius is $0.0020 \mathrm{~m}$, the flame reaches all points in the cylinder before the top dead center and the cylinder pressure and cylinder temperature reaches the maximum level. Therefore, the mean effective pressure acting on the piston towards the end of the expansion time is the maximum level. For this reason, the piston moves to the top dead center and force formation occurs in the opposite direction, and as a result of the negative work area formation, thus the network area is decrease. After the moment of ignition, the flame development was completed at $0.56 \mathrm{~ms}$ for $0.0020 \mathrm{~m}$ flame radius. However, the development time was $1.10 \mathrm{~ms}$ for $0.0005 \mathrm{~m}$ flame radius.

The flame radius is $0.0005 \mathrm{~m}$, it takes time for the flame to reach all the spots in the cylinder and the propagation of flame is delayed, which again has a negative effect on the formation of the network area due to low temperature and pressure.

When reaching the top dead center, the flames with radii of $0.0010 \mathrm{~m}$ and $0.0020 \mathrm{~m}$ reach all the points in the cylinder, while the flame with a radius of $0.0005 \mathrm{~m}$ still does not reach an area of approximately $25 \%$ in-cylinder. Since the flame radius is small, the development of the cylinder is slow after the flame formation.

This causes the maximum pressure to be generated at mid-work due to the slow progress of the flame in spark-ignition engines where the maximum in-cylinder pressure is required immediately after the top dead center, resulting in a decrease in the network area for this reason. As a result, all investigations show that the ideal radius of flame for the specified operating conditions is $0.0010 \mathrm{~m}$.

\section{Conclusion}

In this study, a sequential spark ignition engine characteristics were determined for different flame radii via 3-D modelling approach.

As a result of the study carried out, it was determined that the optimal ignition flame radius for the specified operating conditions is $0.0010 \mathrm{~m}$. When the flame radius was doubled $(0.0020 \mathrm{~m}), 13 \%$ reduction was observed on the power due to the premature completion of combustion and the early formation of the effective temperature and pressure.

When the flame radius is reduced to half $(0.0005$ $\mathrm{m})$, the maximum pressure and temperature formation occurs at the middle of the expansion time as a result of the slow progress of the flame in the cylinder. For this reason, the power drops by about $15 \%$.

Determination of the flame radius directly affects the reaction mechanisms. The small radii cause the temperature to be low, causing the amount of $\mathrm{NO}_{\mathrm{x}}$ to decrease, but not the whole of the mixture to enter the reaction. Large-radius 
flame formation allows the flame to penetrate the entire mixture. Since the high temperatures in the cylinder occur, the amount of $\mathrm{NO}_{\mathrm{x}}$ increases. For these reasons, determining the optimum flame diameter is important for the formation of emissions.
The study shows that the optimum radius of flame for the specified operating conditions is $0.0010 \mathrm{~m}$. Depending on engine operating conditions, variable spark plug gap, multiple spark plug or sequential spark use for smaller flame radius formation can be used to achieve more efficient flame propagation in engine.
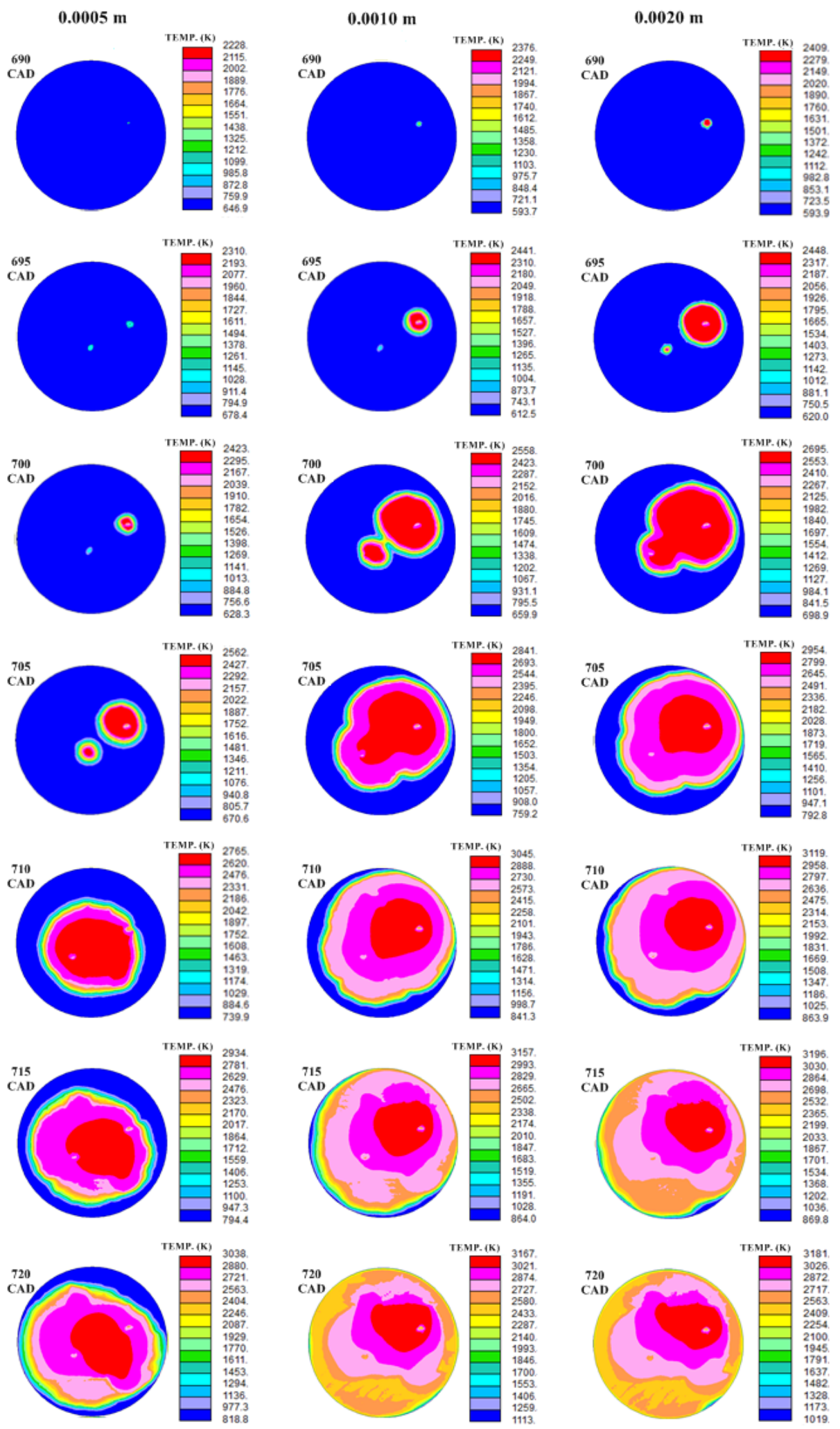

Figure 10. Effects of flame radius on flame formation and propagation 


\section{Acknowledgments}

This study was supported by the Scientific Research Coordination Unit of Kirıkkale University.

\section{References}

[1] Chen, Z., Michael P. B., and Yiguang, J. "On the Critical Flame Radius and Minimum Ignition Energy for Spherical Flame Initiation." Proceedings of the Combustion Institute 33.1, 1219-1226, 2011.

[2] Malaguti, S., and Fontanesi, S. "CFD Investigation of Fuel Film Formation within a GDI Engine under Cold Start Cranking Operation." ASME 2009 Internal Combustion Engine Division Spring Technical Conference. American Society of Mechanical Engineers, 2009.

[3] Yontar, A. A., Kantaroğlu, E., and Doğu, Y., "Ateşleme Avansının Motor Performansina ve Egzoz Emisyonlarına Etkilerinin Sayisal Olarak Incelenmesi.”, 13. Uluslararas1 Yanma Sempozyumu, Bursa, Türkiye, 2015.

[4] Kelley, A. P., and Law, C. K. "Nonlinear Effects in the Extraction of Laminar Flame Speeds from Expanding Spherical Flames." Combustion and Flame, 156(9), 1844-1851, 2009.

[5] Huang, Z., Zhang, Y., Zeng, K., Liu, B., Wang, Q., and Jiang, D. "Measurements of Laminar Burning Velocities for Natural Gas-Hydrogen-Air Mixtures." Combustion and Flame, 146(1), 302-311, 2006.

[6] Dowdy, D. R., Smith, D. B., Taylor, S. C., and Williams, A. "The Use of Expanding Spherical Flames to Determine Burning Velocities and Stretch Effects in Hydrogen/Air Mixtures." In Symposium (International) on Combustion, Vol. 23, No. 1, pp. 325-332, 1991.

[7] Kelley, A. P., Jomaas, G.,and Law, C. K. "Critical Radius for Sustained Propagation of Spark - Ignited Spherical Flames." Combustion and Flame, 156(5), 1006-1013, 2009.

[8] Hepkaya, E., Karaaslan, S., S1tk1, U. S. L. U., Dinler, N., and Yucel, N. "A Case Study of Combustion Modeling in a Spark Ignition Engine Using Coherent Flame
Model.” Journal of Thermal Science and Technology, 34(2), 111-121, 2014.

[9] Deshaies, B., and Joulin, G. "On the Initiation of a Spherical Flame Kernel." Combustion Science and Technology, 37(3-4), 99-116, 1984.

[10] Pischinger, S., and Heywood, J. B. "A Model for Flame Kernel Development in a Spark-Ignition Engine." Proceedings of The Combustion Institute, Vol. 23, No. 1, pp. 1033-1040, 1991.

[11] Migita, H., Amemiya, T., Yokoo, K., and lizuka, Y., The New 1.3-Liter 2-Plug Engine for the 2002 Honda Fit, JSAE Review, Vol. 23(4), pp. 507-511, 2002.

[12] Nakayama, Y., Suzuki, M., Iwata, Y., and Yamano, J., Development of a 1.3 L 2-Plug Engine for the 2002 Model 'Fit', Honda R\&D Technical Review, Vol. 13(2), pp. 4352, 2001.

[13] Star Methodology for Internal Combustion Engine Applications 4.26, CD-Adapco, 2016.

[14] Mahle GmbH, Pistons and Engine Testing, ATZ/MTZ-Fachbuch, 2012.

[15] Mahle GmbH, Cylinder Components, ATZ/MTZ-Fachbuch, 2014.

[16]Heywood, J. B., Internal Combustion Engine Fundamentals, McGraw-Hill College, 1988.

[17] Miller, R., Davis, G., Lavoie, G., Newman, C., and Gardner, T. "A Super-Extended Zel'dovich Mechanism for NOx Modeling and Engine Calibration." No. 980781, SAE Technical Paper, 1998.

[18]Pilling, M. J. "Low-Temperature Combustion and Autoignition." Vol. 35, 1997. 